\title{
An Intractable Case of MPO-ANCA-associated Middle Ear Disease
}

\author{
Seiichiro Kamimura ${ }^{1)}$, Aki Endo ${ }^{2)}$, Koji Abe ${ }^{1)}$, \\ Yoshiaki Kitamura $^{1)}$ and Noriaki Takeda ${ }^{1)}$
}

\begin{abstract}
We report herein on an intractable case of MPO-ANCA-associated middle ear disease with sensorineural hearing loss and facial palsy. A 73-year-old female complained of otitis media-like symptoms, but the treatment for otitis media with effusion was ineffective. She then showed bilateral progressive sensorineural hearing loss and facial palsy. PR3-ANCA was negative, but MPO-ANCA was positive in the serum. CT imaging revealed that the lesion was limited to the middle ear cavity without lesions in the lung and kidney. Non-specific findings were obtained in the histopathological examination of granular tissue of the mastoid cavity. She was diagnosed as having MPO-ANCA-associated middle ear disease with sensorineural hearing loss and facial palsy on the basis of the clinical findings and we administered cyclophosphamide in addition to a steroid. Discontinuance of the immunosuppressive therapy was, however, forced because of bacterial infection. Thereafter, steroid therapy alone failed to improve the left deafness, right moderate sensorineural hearing loss and right facial palsy.
\end{abstract}

Keywords : MPO-ANCA-associated middle ear disease, MPO-ANCA, PR3-ANCA, immunosuppressive therapy

\section{References}

1）吉田雅治：Wegener 肉芽腫症。日臨 63：323-329, 2005.

2) 吉田雅治：抗好中球細胞質抗体（ANCA）サブセットと疾 患. 臨免疫 28: 1214-1222, 1996.

3）武田憲昭，神村盛一郎，千田いづみ，他：感音難聴と顔面 神経麻痺を示す MPO-ANCA 関連中耳疾患の 1 例：診断基 準案の提案. Otol Jpn 21：808-815, 2011.

4) Jennette JC, Falk RJ, Andrassy K, et al. : Nomenclature of systemic vasculitides. Proposal of an international consensus conference. Arthritis Rheum 37: 187-192, 1994.

5) Fauci AS, Haynes BF, Katz P, et al. : Wegener's granulomatosis: prospective clinical and therapeutic experience with 85 patients for 21 years. Ann Intern Med 98: 76-85, 1983.

6) 原㴊保明, 形浦昭克: Wegener 肉芽腫症. CLIENT21 No. 12 鼻 (夜陣紘治編)。345-355 頁, 中山書店, 東京, 2000 .

7）高山雅裕, 柴田敏之, 陽川知江, 他: 耳症状で初発した cANCA 陰性 Wegener 肉芽腫症例. Otol Jpn 11：289, 2001.
8）油川陽子, 片山隆行, 榎本 雪, 他 : 症例 MPO-ANCA 陽 性で両側感音性難聴と頭痛をきたした 1 例. 内科 101：812814, 2008.

9) Takaoka M, Hagiwara A, Hasegawa T, et al. : A case of Wegener's granulomatosis developing with isolated otitis. Pract Otol (Kyoto) 103: 201-208, 2010.

10） 白㴊 肇，児玉 梢，滝沢克己，他：顔面神経麻痺を来し た MPO-ANCA 陽性の中耳炎 2 症例. 日耳鼻会報 113：6771,2010 .

11）中川俊一，柏村正明，古田 康，他：P-ANCA 陽性を示し た内耳炎の 2 症例. Otol Jpn 8: 309, 1998.

12）渡邊弘樹, 坂本 徹, 間口四郎：MPO-ANCA 陽性で進行性 感音難聴に顔面神経麻痺を合併した一例. Otol Jpn 11：290, 2001.

13）尾崎承一, 槇野博史, 松尾清一：4.2 寛解導入療法. ANCA 関連血管炎の診療ガイドライン。40-51 頁, 厚生労働省 難治性疾患克服研究事業, 2011. 